\title{
SELECTED SATURATED CHLORINATED HYDROCARBONS AND THEIR PROPERTIES IN RELATIONSHIP OF RESISTANCE OF BUTYL-RUBBER POLYMERIC MATERIALS
}

\author{
Pavel Otř́ísal $^{1}$--- Stanislav Florus ${ }^{2}$ \\ ${ }^{1,2}$ NBC Defence Institute of University of Defence, Sídliště Vita Nejedlého, Vyškov, Czech Republic
}

\begin{abstract}
The article describes how to test isolative resistance times of the protective folio based on a polyamide carrier fabric coating with butyl-rubber polymer mixture measured by the linear substituted saturated chlorinated aliphatic hydrocarbons. Information about quality of means of isolative protection is very important. Their availability may be limited, and therefore, in some cases will need to rely on the value of breakthrough times for basic hydrides of hydrocarbons, which are not substituted.
\end{abstract}

Keywords: Butyl-rubber (IIR), Chemical resistance, Chlorinated hydrocarbon, QCM detector, Permeation, Breakthrough time (BT).

\section{INTRODUCTION}

Protective properties of protective means against a particular kind of contaminants are not always known. In a case of necessity to work in the contaminated area, however, two approaches exist - neither do not enter the contaminated area after contamination with a chemical substance for which values of breakthrough times (BT) are unknown which is not always possible, nor based on BTs' knowledge for similar chemical compounds, generally for basic hydrids to expertly assess the constructive material's resistance for an under interest substance. The BT's value affects many factors such as temperature, a type and concentration of a harmful substance, the type of a barrier layer and its thickness. The knowledge about resistance of means of body surface protection against under interest toxic compounds is important not only for user's protective means but also for workers who either manage or plan the activities in a contaminated area. In case of known BT for the particular chemical substance and its relationship to the type of protective means, it is not necessary to mutually combine constructive materials. If it is not kept the lack of information can be an obstacle for professional estimation of another kind of barrier material's resistance for under interest contaminants. In such a case it is possible to be fully concentrated only on outer factors such as temperature, the contaminant's type and concentration of contaminants. 


\section{PROBLEMS OF BOTH FINDING AND ASSESSMENT OF BTS WITH THE HELP OF QCM DETECTION}

Constructive materials' BTs is performed for the under interest chemical compound's liquid phase as a rule. Although it is done from a reason of creation of maximal concentration gradient and the indemnity of constant conditions for chemical compounds' permeation through barrier materials, within practical employment in real conditions either it is not going to be reached or quite exceptionally for a short period of time. That is why it is possible to reduce the estimation of chemical resistance only for mutual similarity of chemical compound structure and a character and type of substituents for them values of BTs are known. For the estimation of resistance it is important to consider the temperature within the activity is going to be running.

Measurement of chemical resistance of isolative protective folio used for construction of means of body surface protection is conducted in accordance to norm of ČSN EN ISO 6529 [1] (in case of European Union EN ISO 6529). The resistance of protective means is indicated with the selection into classes according to the norm of ČSN EN 340 (83 2701) [2]. For estimation of chemical resistance (or BTs) is, however, necessary to know not resistance of particular means in conformity with the norm (it means in accordance of classes) but in keeping with time of resistance, which is actually $\mathrm{BT}$. This information has more commercial importance which can be found with the use of other methods (conductivity, colorimetric principle etc.). For BTs introduced in this paper an apparatus used a QCM detector (sensor) with the polymeric layer has been employed [3]. A constructional set of both the permeation cell arrangement and measurement device is stated on Figure 1.

Figure-1. A principled set of permeation cell and device with QCM detector for isolative protective folios' chemical resistance measurement

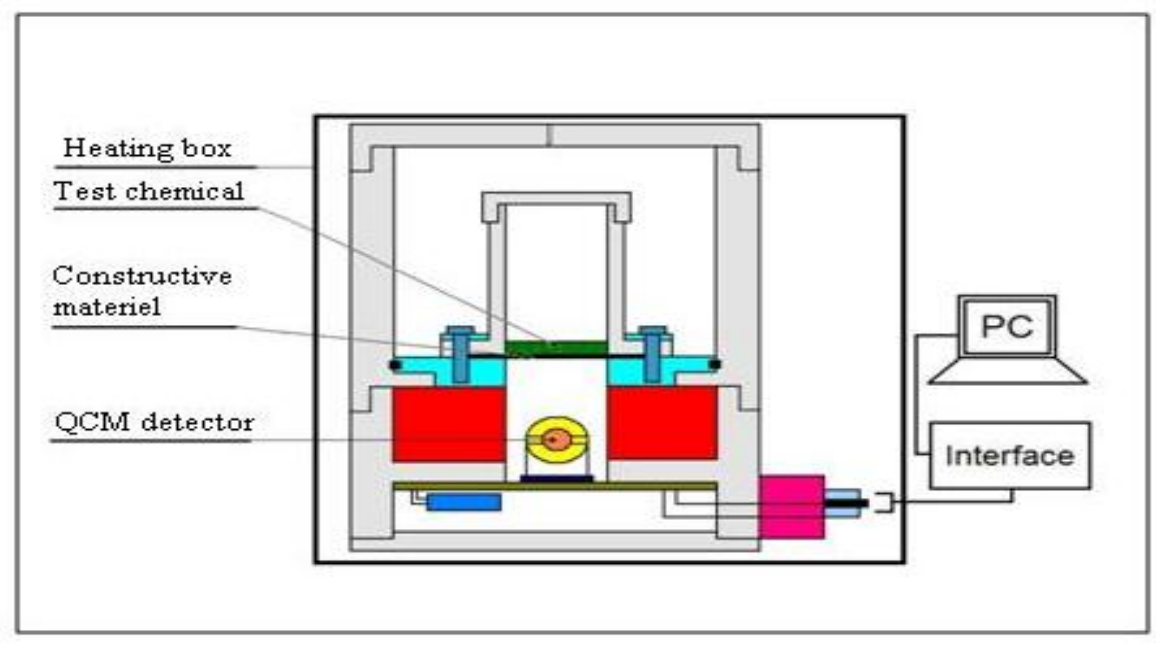

The QCM sensor with the polymeric layer works as a very sensitive microbalance. The caught chemical compound in its polymeric layer causes a change of QCM detector working frequency. Due to this QCM detector behavior it can be found and afterwards devoted the time of 
loss of protective properties. In practice it is done from the increase of the change of the QCM detector working frequency in time. The particular time of protective properties loss has been, in accordance with Bromwich [4], read as so called Lag-Time ( $t,[\min ])$. Lag time basically expresses the value of the steady state of permeation rate through researched constructive materiel. The steepness of a curve part expressing steady state of permeation rate tells about the speed of factual protective properties of researched isolative materiel loss, thus even about concentration of harmful substance increasing on a underside of protective means which is in its under mean part.

\section{MEASUREMENT RESULTS AND THEIR DISCUSSION}

With the help of permeation cell equipped by the QCM detector with the polymeric layer BTs for selected chlorinated hydrocarbons have been measured. For measurement of the isolative protective folio with the carrier layer made from a polyamide fabric with both-sided deposit of IIR with an overall areal weight of 400 g. $\mathrm{cm}^{-2}$ has been employed. Measurements have been performed in the temperature of $30{ }^{\circ} \mathrm{C}$. The researched fabric has been up interlaced with $2 \mathrm{~cm}^{3}$ of test chemical in a permeation cell's dosing area. Measurements' results of fabric's resistance for selected saturated chlorinated hydrocarbons are tabled in a Table 1.

Table-1. BTs values [min] for selected chlorinated hydrocarbons

\begin{tabular}{lll}
\hline Chemical compound & $\begin{array}{l}\text { Minimal value of } \\
\text { BT, [ } \mathbf{m i n}]\end{array}$ & $\begin{array}{l}\text { Minimal value of researched materiel } \\
\text { thickness, [mm] }\end{array}$ \\
\hline Dichloromethane & 6,9 & 0,349 \\
\hline 1,2-Dichloroethane & 7,3 & 0,335 \\
\hline Trichloromethane & 6,2 & 0,346 \\
\hline 1,1,2-Trichloroethane & 18,3 & 0,332 \\
\hline 1,3-Dichloropropane & 18,1 & 0,335 \\
\hline Tetrachloromethane & 21,7 & 0,351 \\
\hline 1,1,2,2-Tetrachloroethane & 46,8 & 0,348 \\
\hline 1,6-Dichlorohexane & 78,7 & 0,333 \\
\hline
\end{tabular}

If researched isolative protective folio with barrier layer made from IIR's BTs are compared in accordance with a chemical structure of test chemical it can be seen that the test chemical's chemical structure affects permeation. The BT dependence on the test chemical's chemical structure is evident from Figure 2. 
Figure-2. Dependency of isolative protective fabric with barrier layer made from IIR's BT on the chemical structure of test chemical.

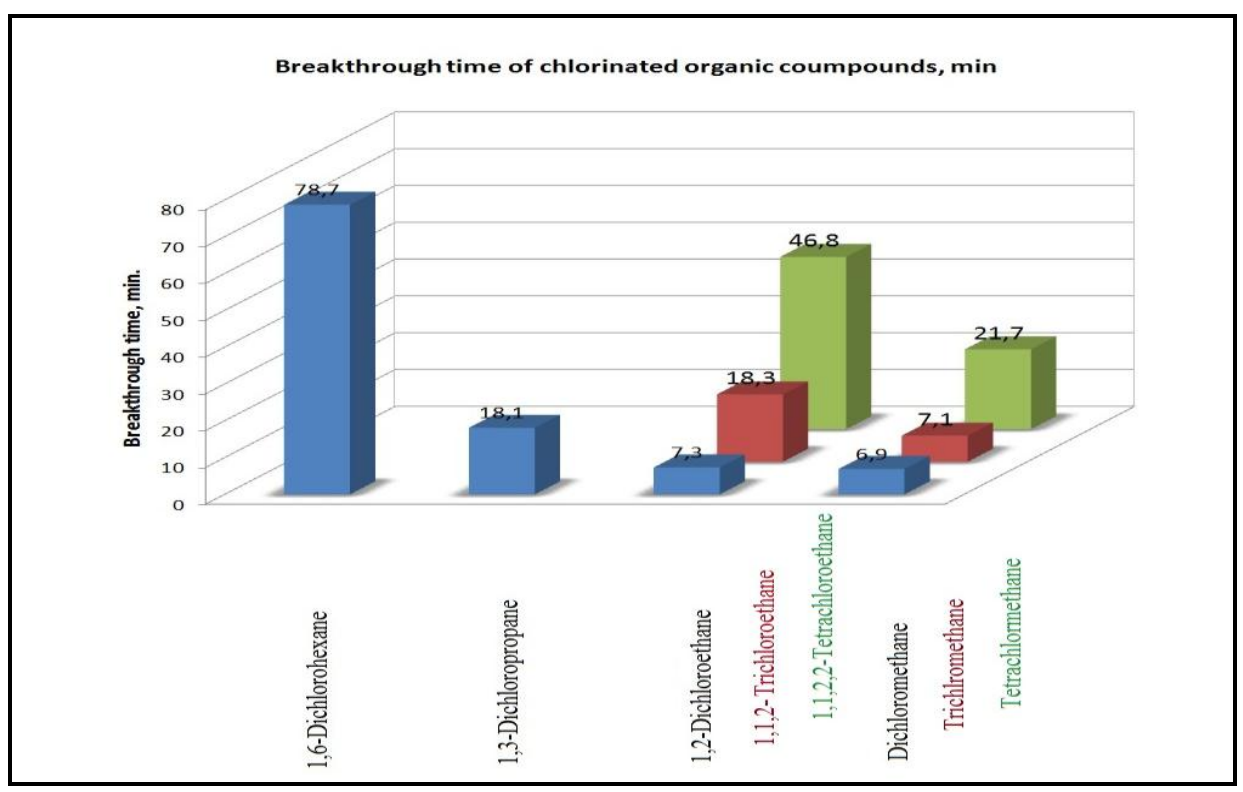

From dependency of the QCM detector working frequency change on time for single test chemical it is clear that researched isolative protective folio for all tested chlorinated hydrocarbons shows quick loss of protective properties (Figure 3). This loss rate can be characterized with the help of an angle which includes a linear part of dependency with a time axis. It is valid that the higher angle $\left(\max .90^{\circ}\right)$ the protective folio is more "open" for test chemical and thus its concentration can quicker increase in under mean part of protective means.

Figure-3. Dependency of QCM detector working frequency on time for selected chlorinated hydrocarbons

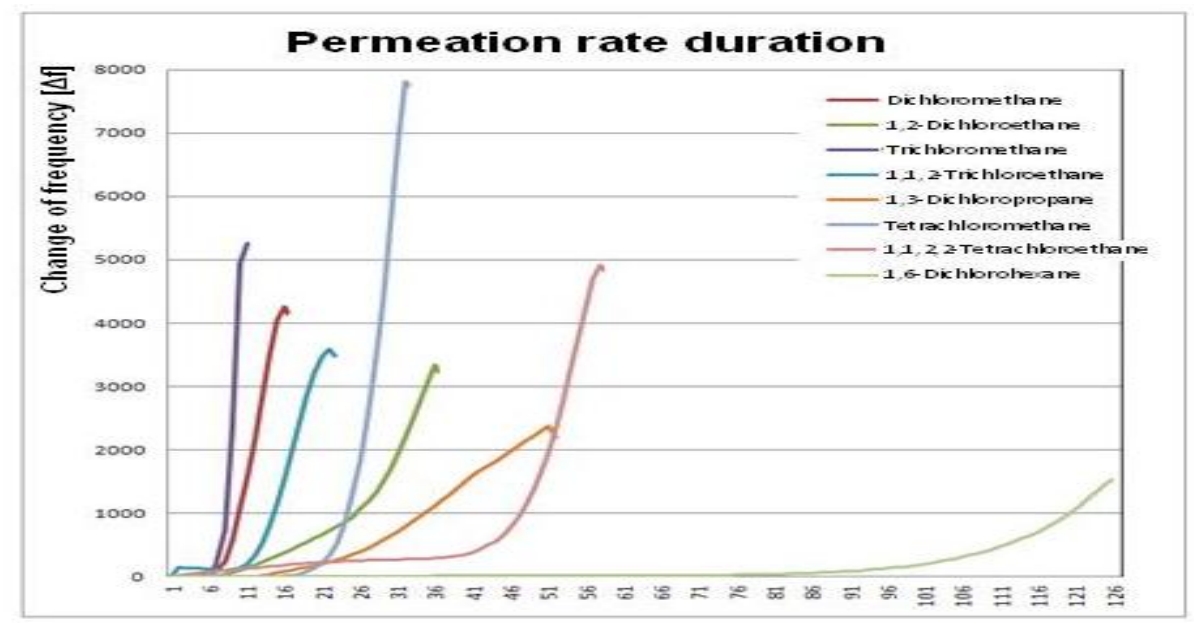


Based on performed measurements a relationship between resistance values and test chemicals' properties has been searched. Based on analyses of available data such as suitable value which would characterize relationship between isolative protective folio with barrier materiel made from IIR's resistance and saturated linear chlorinated hydrocarbons, the rate of molar value has been used (Table 2).

Table-2. Relative molar weight, molar volume of selected chlorinated hydrocarbons, BT and thickness of measured isolative protective folio

\begin{tabular}{|c|c|c|c|c|}
\hline Chemical substance & $\begin{array}{l}\text { Molar } \\
\text { weight, } \\
{\left[\mathrm{g} \cdot \mathrm{mol}^{-1}\right]}\end{array}$ & $\begin{array}{l}\text { Molar volume, } \\
{\left[\mathrm{cm}^{3} \cdot \mathrm{mol}^{-1}\right]}\end{array}$ & $\begin{array}{l}\text { Minimal } \\
\text { value of } \mathrm{BT} \text {, } \\
{[\mathrm{min}]}\end{array}$ & $\begin{array}{l}\text { Middle value of } \\
\text { BT, [min]] }\end{array}$ \\
\hline Dichloromethane & 83,93 & 63,857 & 6,9 & 7,2 \\
\hline 1,2-Dichloroethane & 98,96 & 79,168 & 7,3 & 9,9 \\
\hline Trichloromethane & 119,38 & 80,662 & 6,2 & 6,5 \\
\hline 1,1,2-Trichloroethane & 133,41 & 92,638 & 18,3 & 21,9 \\
\hline 1,3-Dichloropropane & 112,99 & 94,949 & 18,1 & 23,6 \\
\hline Tetrachloromethane & 153,82 & 96,742 & 21,7 & 22,5 \\
\hline 1,1,2,2-Tetrachloroethane & 167,85 & 105,566 & 46,8 & 50,5 \\
\hline 1,6-Dichlorohexane & 155,07 & 144,925 & 78,7 & 87,4 \\
\hline
\end{tabular}

From the chart 2 it is evident molar weight values well correspond with BTs values irrespective the fact that BTs values are affected by isolative protective folio thicknesses.

It is clear that this access will be valid only for the group of chemical compounds which chemical structure will not be dramatically different, for example within homologues, alkyl benzenes with different degree of alkylation etc.

\section{CONCLUSION}

Estimation of the chemical resistance of protective isolation folio based on the similarity structure of chemical substances structure can be particularly at highly toxic substances, such as the type of chemical warfare agents, one of the possible approaches to predict the risk for people working in a contaminated environment. In some situations it may be the knowledge of chemical resistance of insulating coatings in relation to the basic hydrocarbons hydrids sufficient and usable in a situation where the data for the chlorine substituted contaminants are not available. In this case, it can be significantly reduced the health hazard caused by improper and mainly long term long-term use of isolative protection equipment, which have lost their declared chemical resistance.

\section{REFERENCES}

[1] ČSN EN ISO 6529, Ochranné oděry - Ochrana proti chemikáliźm - Stanovení odolnosti ochranných oděvi proti permeaci kapalin a plynů. Praha: Český Normalizační Institut, 2002.

[2] ČSN EN 340 (83 2701), Ochranné oděry - Všoobecné požadavky vol. 27s.s. Praha: Český Normalizační Institut, 2004. 
[3] S. FLORUS, P. OTŘíSAL, and V. OBŠEL, "Posibilities of usage a piezoelectric detektor to measure the brekthrough time of protective material. In symposium proceedings, NBC 2009. 7th symposium on CBRNE threars. Meeting the future challenges," Finland: Jyväskylä, Defence Forces Technical Research Centre. (PDF), ISSN: 1457-3938, 2009, pp. s 239-243.

[4] D. W. Bromwich, The design of permeation cells for testing chemical protective clothing. Brisbane: Grifith University, 1999. 